\title{
A Splice Junction Mutation Causes Deletion of a 72-Base Exon from the mRNA for Lysosomal Acid Lipase in a Patient with Cholesteryl Ester Storage Disease
}

\author{
Horst Klima, Kurt Ullrich, * Charalampos Aslanidis, Petra Fehringer, Karl J. Lackner, and Gerd Schmitz \\ Institut für Klinische Chemie und Laboratoriumsmedizin, Universität Regensburg, D-93042 Regensburg, Germany; \\ and ${ }^{*}$ Klinik und Poliklinik für Kinderheilkunde, Westfälische Wilhelms-Universität, Münster, Germany
}

\section{Abstract}

The genetic defect leading to cholesteryl ester storage disease (CESD) has been determined in a 12-yr-old patient. Lysosomal acid lipase (LAL) activity in cultured skin fibroblasts was reduced to $\sim 9 \%$ of control fibroblasts. Plasma cholesterol ( $255 \mathrm{mg} / \mathrm{dl})$ and LDL-cholesterol $(215 \mathrm{mg} / \mathrm{dl})$ were elevated whereas HDL-cholesterol was reduced $(19 \mathrm{mg} / \mathrm{dl})$. Triglycerides were moderately elevated $(141 \mathrm{mg} / \mathrm{dl})$. There were no clinical abnormalities with the exception of hepatosplenomegaly. Both parents have reduced LAL activity in white blood cells. PCR analysis of the LAL mRNA from the propositus revealed a single slightly smaller mRNA species in skin fibroblasts as well as in leukocytes. The mother of the patient and his older brother had two mRNA species: one of normal size and one of the same size as the propositus. The father has a LAL mRNA of normal size only. Sequence analysis of a PCRamplified cDNA fragment showed a 72-bp in-frame deletion resulting in the loss of the codons for amino acids 254-277. Analysis of genomic DNA revealed that the 72 bp represent an exon, indicating that the deletion in the mRNA is caused by defective splicing. Sequence analysis of the patient's genomic DNA revealed a $G \rightarrow A$ substitution in the last nucleotide of the 72-bp exon in one of his alleles. The mutant allele was shown to cosegregate with the truncated mRNA in the pedigree, providing further evidence that the $G \rightarrow$ A substitution causes aberrant splicing and exon skipping. No normal-sized mRNA is detectable in the propositus even though he is not homozygous for the splice site mutation. This can be only accounted for by assuming that he is a compound heterozygote with a null allele inherited from his father. In summary, the data presented provide evidence that deletion of the codons for amino acids 254 277 in the LAL mRNA in combination with a null allele cause the clinical expression of CESD in our patient. (J. Clin. Invest. 1993. 92:2713-2718.) Key words: acid cholesteryl ester hydrolase $\bullet$ acid lipase $\bullet$ cholesteryl ester storage disease $\bullet$ lysosomal acid lipase deficiency $\bullet$ splicing defect

Address reprint requests to Dr. med. G. Schmitz, Institut für Klinische Chemie und Laboratoriumsmedizin, Universität Regensburg, D-93042 Regensburg, Germany.

Received for publication 2 April 1993 and in revised form 28 June 1993.

J. Clin. Invest.

(c) The American Society for Clinical Investigation, Inc. 0021-9738/93/12/2713/06 \$2.00

Volume 92, December 1993, 2713-2718

\section{Introduction}

Lysosomal acid lipase (LAL) ${ }^{1}$ (acid cholesteryl ester hydrolase) plays an important role in cellular processing of plasma lipoproteins, and thus contributes both to the homeostatic control of plasma lipoprotein levels and to the prevention of cellular lipid overload in the liver, spleen, and macrophages or transformed smooth muscle cells of the arterial wall (1).

Deficient activity of LAL results in massive accumulation of cholesteryl esters and triglycerides in most tissues of the body (2). Both of these lipids are substrate for the enzyme; however, the hydrolysis of lipoprotein-bound cholesteryl esters is preferential. The genetic deficiency state of LAL is expressed in two major phenotypes: Wolman's disease (WD) and cholesteryl ester storage disease (CESD) (2). Both diseases are inherited as autosomal recessive traits. WD is nearly always fatal before the age of $1 \mathrm{yr}$. Hepatosplenomegaly, steatorrhea, abdominal distension, other gastrointestinal symptoms, adrenal calcification, and failure to thrive are observed in the first weeks of life. Besides the infantile form of WD, other forms may exist that are of later onset, lack adrenal calcification, and follow a less severe and more prolonged clinical course (3-6). CESD is more benign and may not be detected until adulthood. Lipid deposition is widespread although hepatomegaly may be the only clinical organ manifestation. Adrenal calcification is rare. Hyperbetalipoproteinemia is common in CESD, and premature atherosclerosis may be severe, whereas patients with WD usually succumb to liver failure in infancy before vascular changes have had a chance to become manifest. It is not known whether WD and CESD are only different expressions of defects in the LAL gene or represent defects in different genes.

LAL activity may be relevant in the pathogenesis of arteriosclerosis. In freshly isolated mononuclear cells from patients with premature coronary heart disease (7) or arteriosclerosis of the carotid arteries ( 8 ) and patients with familial hypercholesterolemia and familial combined hyperlipidemia, (9) LAL activity was significantly reduced compared to cells from agematched controls. Some forms of hypertension may also impair aortic wall LAL activity $(10,11)$.

Diagnosis of CESD and WD is still based on the clinical picture combined with the demonstration of LAL deficiency in cultured skin fibroblasts, leukocytes, or other tissues (2). The LAL gene is located on chromosome 10 (12-14). Recently the full-length cDNA has been cloned (15). The enzyme is structurally related to previously described enteric acid lipases, but

1. Abbreviations used in this paper: CESD, cholesteryl ester storage disease; LAL, lysosomal acid lipase; RT, reverse transcription; WD, Wolman's disease. 
lacks significant homology with any characterized neutral lipase. To our knowledge, no mutations in the LAL gene have been reported so far. Specific molecular defects leading to CESD or WD are unknown. Here, we present data showing that a specific mutation in the LAL gene is associated with CESD.

\section{Methods}

Culture of skin fibroblasts. Skin fibroblasts were cultured according to standard protocols in DME supplemented with $1 \%$ L-glutamine, $1 \%$ nonessential amino acids, and $10 \%$ fetal calf serum in a humidified atmosphere containing $5 \% \mathrm{CO}_{2}$. CESD and normal fibroblasts were used between passages 5 and 15. Cells were grown to confluence and used for the enzyme assay after at least $2 \mathrm{~d}$ at confluence.

Isolation of RNA and DNA. Total RNA and DNA were isolated from cultured skin fibroblasts or white blood cells. RNA was isolated using the isothiocyanate/cesium chloride method as described by Chirgwin et al. (16). Isolation of genomic DNA was carried out as described by Miller et al. (17).

Reverse transcription/polymerase chain reaction ( $R T / P C R)$. First-strand cDNA was synthesized from total RNA by oligo dT priming, using a commercially available kit (Promega Corp., Madison, WI) according to the instructions of the manufacturer. The protein coding sequence and the noncoding region were amplified by overlapping PCR using a series of synthetic oligonucleotide primers (see also Fig. 3):

LAC1-5' CCCGGCAGGACAGCTCCAGA 3';

LAC2-5' GTGTGACACAGCTCAAGTCCAGCTT 3';

LAC3-5' ATACAATGTGAAGGACATGC 3';

LAC4-5' CCTATAAGTCTCACTCAATT 3'.

After RT the reaction mixture was mixed with 30 pmol of the appropriate PCR primers in a total volume of $100 \mu \mathrm{l}$ containing $5 \mathrm{mM} \mathrm{MgCl}$ and 2.5 U Taq polymerase (Cetus Corp., Emeryville, CA). All PCRs were carried out in a Perkin-Elmer Cetus (Norwalk, CT) thermocycler using the following protocol: denaturation $90 \mathrm{~s}$ at $94^{\circ} \mathrm{C}$, annealing $90 \mathrm{~s}$ at $58^{\circ} \mathrm{C}$, elongation $120 \mathrm{~s}$ at $72^{\circ} \mathrm{C} ; 30$ cycles. The elongation time of the last cycle was $10 \mathrm{~min}$.

In vitro amplification of genomic DNA. Oligonucleotides used for PCR of genomic DNA were (see Fig. 3):

LAC5: 5' CTTCTGTGTGGATTTAATGAG 3';

LAC6: 5' GTTTTGCACAGAAGTTCCAGCAGGAG 3';

\section{LAC7: 5' CTAGAGTGGATGTATATACAACAC 3';}

\section{LAC8: 5' CCAGATCAGATTTGTAAGCAGGTTG 3'.}

The oligonucleotide pairs were used for amplifying a $1.2-\mathrm{kb}$ and a $176-$ bp fragment from genomic DNA containing three exon intron transitions and the complete 72-bp exon. The PCR conditions were identical to those described for CDNA amplification except that the hybridization temperature was $55^{\circ} \mathrm{C}$ and the final $\mathrm{MgCl}_{2}$ concentration was 2.5 $\mathrm{mM}$. For each PCR reaction $1 \mu \mathrm{g}$ of genomic DNA was used as a template.

Direct DNA sequencing of PCR products. PCR products were separated by electrophoresis through $1.5 \%$ agarose gels. The amplified DNA was extracted from the gel using a glass powder method (Geneclean II, BIO 101, Inc., San Diego, CA). Single-stranded template DNA was generated by asymmetric PCR using $40 \mathrm{ng}$ of the purified PCR product from the first amplification as a template. The DNA was reamplified for 35 cycles in the presence of one primer to generate single-strand DNA. The single stranded DNA (1-2 $\mu \mathrm{g})$ was purified using the Diagen M13 DNA purification kit (Diagen, Hilden, FRG) following the protocol of the manufacturer. DNA sequencing was carried out by the dideoxy chain terminating method (18) using $\left[\alpha^{35} S\right]-$ dATP as radioactive label and the modified T7 DNA polymerase (Sequenase 2.0, United States Biochemical Corp., Cleveland, $\mathrm{OH}$ ).

Cloning and sequencing of amplified genomic DNA. PCR products obtained from genomic DNA as described above were blunt end ligated into the Hincll site of the plasmid pUC18 (19). Plasmid DNA was sequenced using the Sequenase $2.0 \mathrm{kit}$, according to the instructions of the manufacturer. The sequence was analyzed on an automatic DNA sequencer (Automated Laser Fluorescence, Pharmacia, Uppsala, Sweden).

Isolation of genomic clones for $L A L$. A commercially available human genomic library in lambda FIX II (Stratagene, Inc., La Jolla, CA) was screened with the $1.2-\mathrm{kb} \mathrm{cDNA}$ fragment containing the coding sequence of LAL from positions 21 to 1265 (15). Eight positive lambda clones were purified and digested with Xbal for Southern blot analysis (19). For sequencing fragments were subcloned into pUC18.

Measurement of LAL activity. Enzyme activity was measured from cell lysates of skin fibroblasts and white blood cells as described previously (20). The only difference from the published procedure was the use of $\left[1 \alpha, 2 \alpha(\mathrm{n})-{ }^{3} \mathrm{H}\right]$ cholesteryl oleate as substrate instead of $\left[{ }^{14} \mathrm{C}\right]-$ oleate-labeled cholesteryl ester. The protein concentration of cell lysates was determined according to the method of Lowry et al. (21). LAL activity is given as picomoles of cholesterol released per milligram of protein during a $60-\mathrm{min}$ incubation.

\section{Results}

Patient presentation. The patient is the second child of healthy unrelated parents. His two brothers ( 14 and $3 \mathrm{yr}$ ) are both asymptomatic. The family derives from a Polish-German origin. At the age of $5 \mathrm{yr}$ hepatosplenomegaly was detected at a routine examination in the propositus without significant clinical symptoms. The liver was palpable $8 \mathrm{~cm}$ and the spleen $3 \mathrm{~cm}$ below the costal margin. No adrenal calcification could be detected. Lipid analysis from liver tissue revealed significant cholesteryl ester storage. Electron microscopy showed cholesterol crystals as well as multivesicular storage of lipids both in parenchymal cells as well as in Kupffer cells. The diameter of the vesicles were between 1 and $5 \mu \mathrm{m}$ with a tendency to a smaller diameter in the Kupffer cells. In parenchymal cells vesicular/ droplet-like lysosomes dominated, whereas in liver sinusoidal cells crystal cleftlike lysosomes were predominant. There were no obvious signs of increased fibrosis.

Plasma cholesterol and LDL-cholesterol levels were significantly elevated while HDL-cholesterol was reduced (Table I). Plasma triglycerides were only slightly elevated. All other clinical and laboratory examinations were normal.

LAL activity was measured in the patient's fibroblasts. The residual activity was $\sim 9 \%$ compared to controls. The enzyme activity was also measured in leukocytes isolated from the patient's family. All members of the family have reduced activity (Table II). In leukocytes the patient's residual LAL activity was found to be only $2 \%$ of control activity.

Analysis of the LAL mRNA by RT/PCR. Total RNA was isolated from cultured skin fibroblasts or from white blood cells of pedigree members, reverse transcribed into cDNA, and the coding and noncoding regions of the LAL mRNA were amplified using the primer pairs LAC1/LAC2 and LAC3/LAC4, respectively. The PCR product of the coding sequence of the patient was smaller in size compared to controls (Fig. 1, lanes 1 and 2), whereas the PCR product from the $3^{\prime}$ nontranslated region was identical in size (data not shown). There was no detectable 5' PCR product of normal size. RNA from the patient's family was also analyzed by RT / PCR with the oligonu- 
Table I. Biochemical and Clinical Data of the Propositus, His Parents, and Siblings

\begin{tabular}{lccccc}
\hline $\begin{array}{c}\text { Initials } \\
\text { (position in the pedigree) }\end{array}$ & $\begin{array}{c}\text { V. W. } \\
(\mathrm{I}-1)\end{array}$ & $\begin{array}{c}\text { M. W. } \\
(\mathrm{I}-2)\end{array}$ & $\begin{array}{c}\text { W. W. } \\
\text { (II-1) }\end{array}$ & $\begin{array}{c}\text { N. W. } \\
(\mathrm{II}-2)\end{array}$ & $\begin{array}{c}\text { M. W. } \\
\text { (II-3) }\end{array}$ \\
\hline Age, yr (sex) & $37(\mathrm{~m})$ & $37(\mathrm{f})$ & $14(\mathrm{~m})$ & $12(\mathrm{~m})$ & $3(\mathrm{~m})$ \\
Cholesterol $(m g / d l)$ & 227 & 226 & 148 & 255 & 202 \\
LDL-cholesterol $(m g / d l)$ & 179 & 164 & 86 & 215 & n.d. \\
HDL-cholesterol $(m g / d l)$ & 21 & 38 & 38 & 19 & 52 \\
Triglycerides $(m g / d l)$ & 209 & 124 & 58 & 141 & 37 \\
ApoB $(m g / d l)$ & 147 & 135 & 72 & 179 & 111 \\
ApoA-I $(m g / d l)$ & 85 & 142 & 119 & 86 & 152 \\
Lipoprotein $(a)(m g / d l)$ & 68 & 8 & 10 & 34 & 0,5 \\
Hepatomegaly & $\varnothing$ & $\varnothing$ & $\varnothing$ & ++ & $\varnothing$ \\
Splenomegaly & $\varnothing$ & $\varnothing$ & $\varnothing$ & + & $\varnothing$ \\
Apo-B 3500 mutation & no & no & no & no & no \\
ApoE phenotype & $3 / 3$ & $3 / 3$ & $3 / 3$ & $3 / 3$ & $3 / 3$ \\
& & & & & \\
\hline
\end{tabular}

Positions in the pedigree correspond to Fig. 4.

cleotides LAC1 and LAC2. The results are shown in Fig. 1 (lanes 4-7). His mother and older brother had both the deleted and normal-sized mRNA, and his father only a normal-sized mRNA. The mRNA of the 3-yr-old brother (II-3) could not be analyzed, because the blood obtained was only sufficient for determination of enzyme activity. The parents denied consent to take another blood sample for RNA analysis.

Sequencing of coding region of $L A L$. Direct sequencing of the region of the CDNA where the deletion was expected was accomplished by asymmetric PCR using primers LAC1/ LAC2. Sequence analysis revealed a 72-bp in-frame deletion in the patient's cDNA (Fig. 2), resulting in the loss of 24 amino acids of the protein (position 254-277). In addition, the cDNA sequence of the propositus has a $\mathrm{C}$ instead of a $\mathrm{T}$ at position 937 when compared to the published cDNA (Fig. 2, right). This $\mathrm{T} \rightarrow \mathrm{C}$ transition affects the third position of the codon $\mathrm{Ala}_{278}$ and does not change the predicted amino acid sequence. When the whole coding region of the LAL mRNA of the propositus ( bases 21-1265) was sequenced after subcloning of the PCR fragment into pUC18, no further differences to the published sequence (15) were detected.

\section{8}

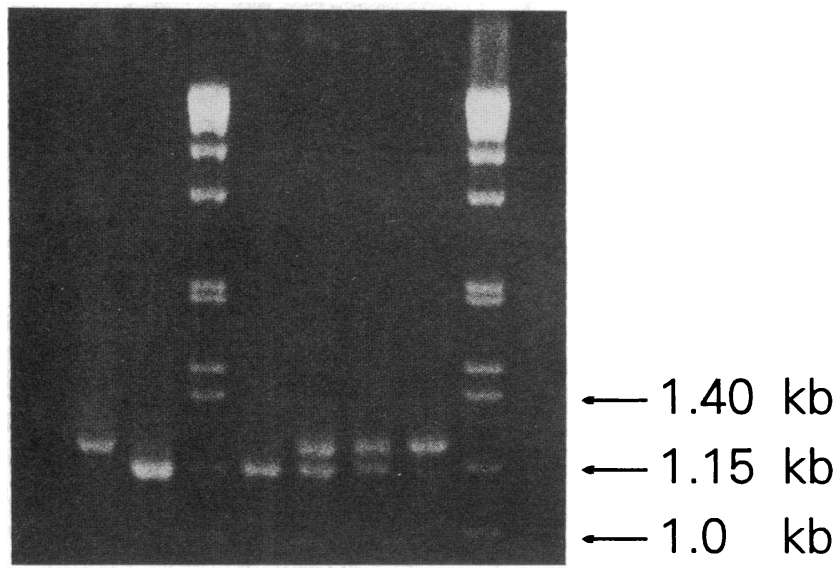

C $\quad$ MW $\quad$ II-1 $\quad \mathrm{H}-1$

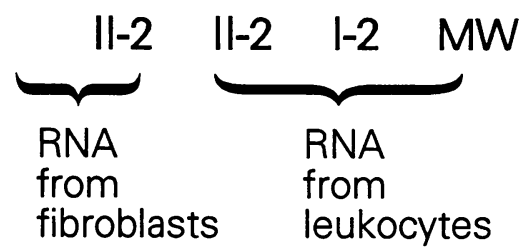

Figure 1. Agarose gel electrophoresis of RT / PCR fragments from four family members and a control. The oligonucleotides LAC1 and LAC2 were used for amplification. RNA was isolated from leukocytes and fibroblasts. Lane 1 , control fibroblasts $(C)$; lane 2, patient (II-2) fibroblasts. Lanes 4-7 represent RNA from leukocytes: Lane 4, patient (II-2); lane 5, brother (II-I); lane 6, mother (I-2); lane 7, father $(I-1)$. Lanes 3 and 8 , molecular weight markers $(M W)$.

Genomic analysis. To determine whether the 72-bp deletion is on the gene level or is due to defective RNA splicing, genomic DNA from the pedigree and the control were digested with Xbal and Southern blots were hybridized with a 1.2-kb cDNA probe containing the coding sequence of LAL. Since the fragment deleted from the mRNA contains an Xbal site, one

Table II. LAL Activity in Leukocytes and Fibroblasts from the Propositus, His Parents, and Siblings

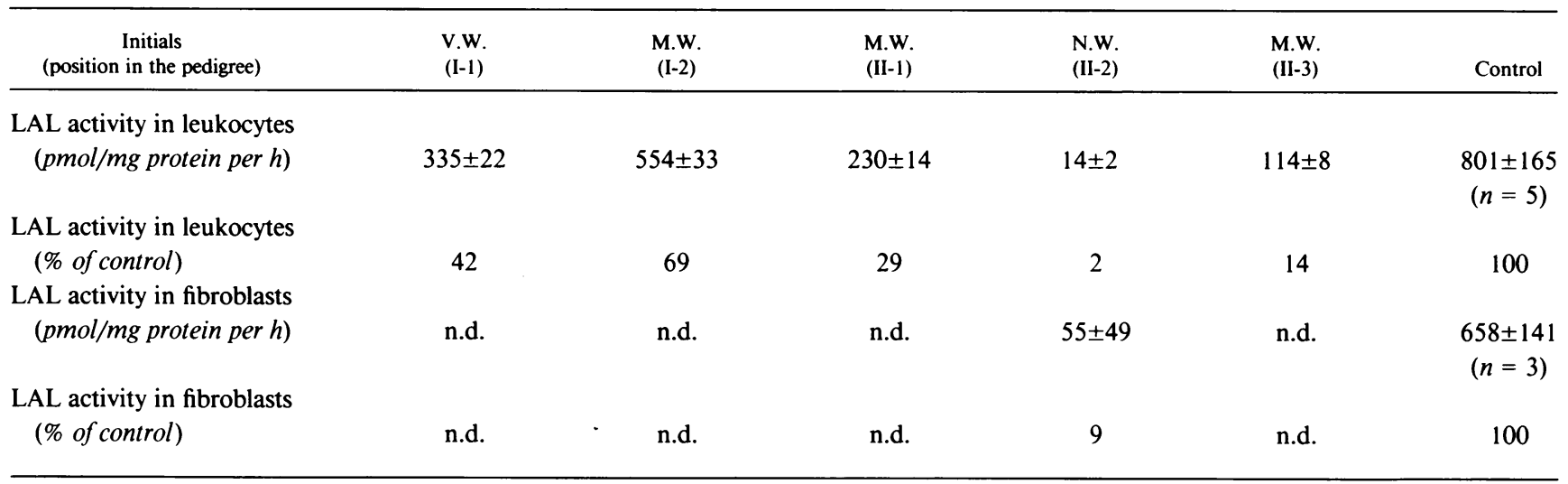

Measurements in an individual's leukocytes represent means of triplicate determinations. The determination of the patient's fibroblasts represent triplicate determinations from two separate cell culture experiments. Leukocytes served as controls from five normolipidemic blood donors or three fibroblast cultures from normolipidemic subjects taken at the time of abdominal surgery. n.d., not determined. 


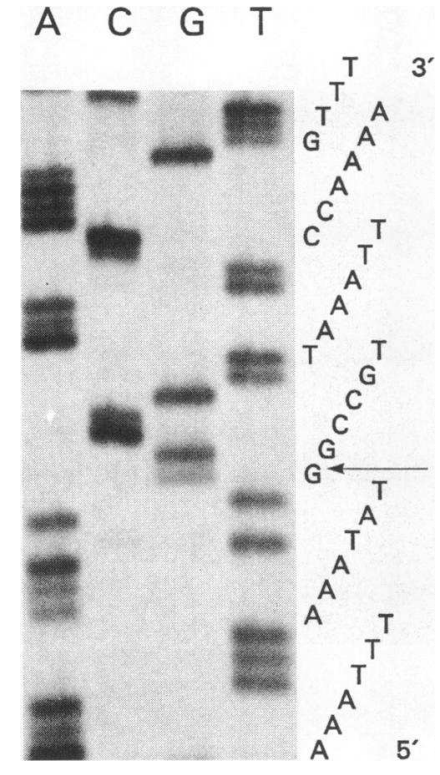

239 Leu Cys Phe Leu Leu Cys Gly Phe Asn Glu Arg Asn Leu

818 CTC TGT TTT CTT CTG TGT GGA TTT AAT GAG AGA AAT TTA

252 Asn Met Ser Arg Val Asp Val Tyr Thr Thr His Ser Pro 857 AAT ATG tot aga gtg gat gta tat aca aca cat tot cet

265 Ala Gly Thr Ser Val Gln Asn Met Leu His Trp Ser Gln

896 get gga act tet gtg caa aac atg tta cac tgg agc cag

278 Ala Val Lys Phe Gln Lys Phe Gln Ala Phe Asp Trp Gly 935 GCT GTT AAA TTC CAA AAG TTT CAA GCC TTT GAC TGG GGA

Figure 2. Left: Total RNA from a patient's (II-2) fibroblasts was reverse transcribed, amplified with primers $\mathrm{LAC} 1$ and $\mathrm{LAC} 2$, and analyzed by direct sequencing as described in Methods. $\sim 300 \mathrm{bp}$ of sequence from either end could be determined. In the cDNA a 72-bp in-frame deletion was detected. The position of the deletion is indicated by an arrow. Right: Partial cDNA sequence of the LAL cDNA with the derived amino acid sequence. Amino acid and nucleotide numbering according to reference 15 . The deleted nucleotides in the CESD patient (II-2) are shown in lower key. The Xbal site is underlined. At position 937 a $\mathrm{T} \rightarrow \mathrm{C}$ transition compared to the published sequence was detected. This does not affect the predicted amino acid sequence. would expect an altered restriction fragment pattern, if the deletion was present on the genomic level. No differences in the patterns of the propositus, the other family members, and a control were detectable, indicating the presence of the Xbal site in the propositus's DNA (data not shown). This was taken as evidence that the defect is caused by defective splicing of the hnRNA.

To further elucidate the genetic defect genomic DNA was amplified. Primers LAC 5/LAC6 allowed the amplification of a $1.2-\mathrm{kb}$ fragment containing the entire 5 '-intron and two exon intron transitions (Fig. 3). PCR amplification of the 3'-intron using primers within the 72-bp exon and the adjacent cDNA sequence expected to be located in the downstream exon was not successful, indicating the presence of a very large intron. Therefore, a genomic lambda library $\left(8 \times 10^{5}\right.$ clones $)$ was screened with the LAL cDNA as a probe to isolate genomic clones. Eight genomic clones were identified and further char- acterized by Southern blotting. A 650-bp Xbal fragment, which hybridized with oligonucleotide LAC6, was sequenced. It contained the complete 72-bp exon and part of the 3 ' flanking intron (intron B). From the intron sequence an oligonucleotide ( LAC8) was synthesized and used for amplification of the $3^{\prime}$ exon intron junction in the patient's DNA (Fig. 3). By sequencing cloned PCR fragments a $G \rightarrow$ A substitution was detected in the last position of the 72-bp exon. 7 of 16 clones sequenced had an $A$ and 9 a $G$ in this position, indicating heterozygosity (data not shown). In the patient's genomic DNA two additional exon intron transitions in the vicinity of the 72-bp exon were analyzed (Fig. 3 and Table III). With the exception of the point mutation there were no other differences between the wild-type sequence and the patient's DNA. Analysis of genomic DNA of the patient's family using the same approach as for the propositus revealed that the father carries two alleles with the wild-type sequence ( $G$ allele) around the

A

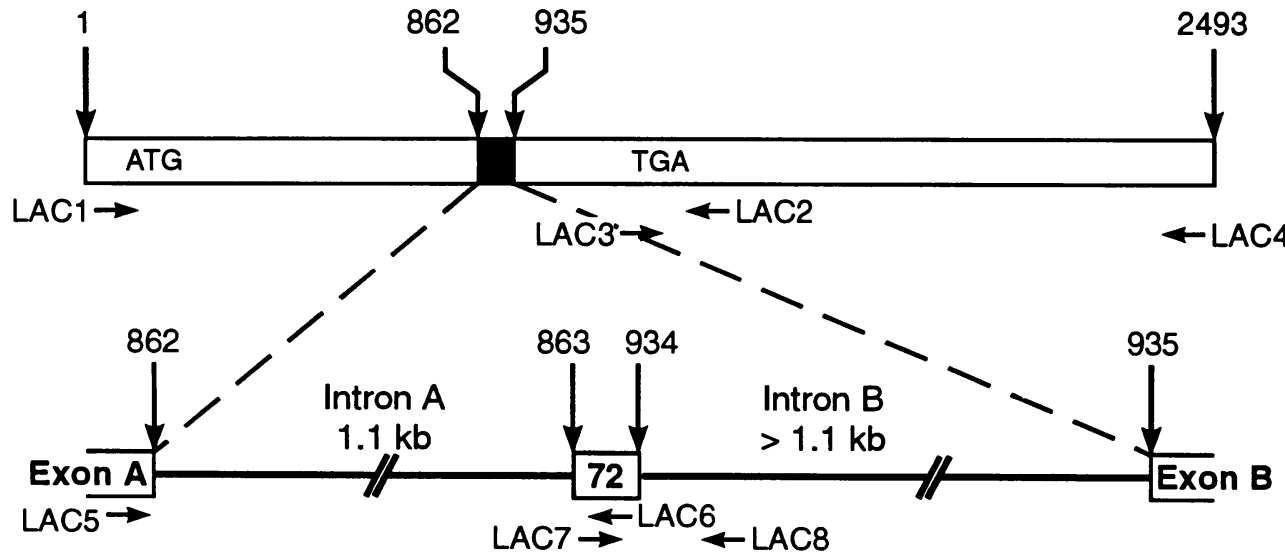

Figure 3. (A) Schematic representation of the $\mathrm{LAL}$ mRNA. The positions of the oligonucleotides used for RT/PCR are indicated by arrows. (B) Partial schematic representation of the LAL gene. The positions of the primers used for amplification of genomic DNA are indicated by arrows. The size of intron A is estimated from gel electrophoresis of amplified DNA. The size of intron $\mathrm{B}$ is not known. $(C)$ Schematic representation of the fragments sequenced from the genomic DNA of the propositus. 


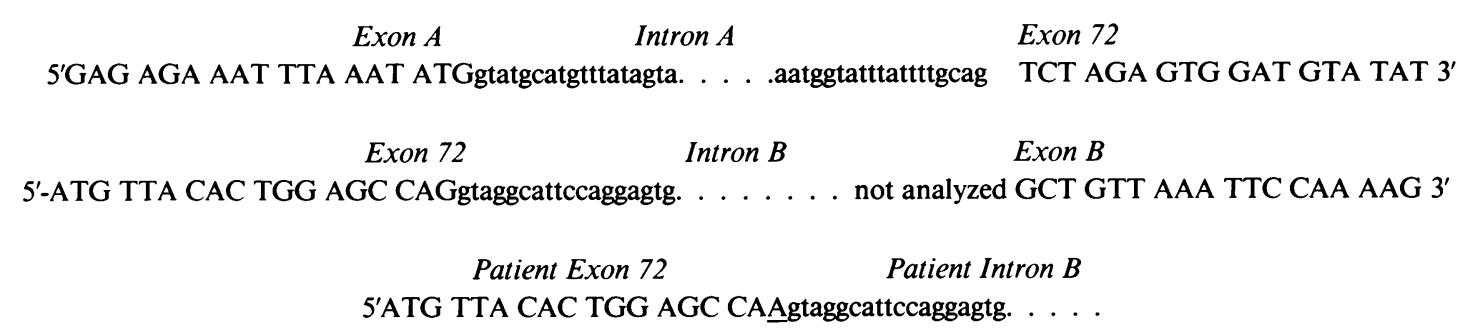

Exon sequences are shown in upper case, intron sequences in lower case. The point mutation in the patient is underlined.

splice site (nine PCR clones out of nine), while the mother ( $5 x$ A allele, $5 x \mathrm{G}$ allele) and the older brother (6x A allele, $4 x \mathrm{G}$ allele) are heterozygous at this locus.

\section{Discussion}

The genetic defect leading to CESD was analyzed in a 12-yr-old boy. The diagnosis of CESD is based on three lines of evidence. (a) Clinically there is hepatosplenomegaly without any other abnormality. (b) Laboratory tests revealed severely reduced LAL activity in fibroblasts and white blood cells and hypercholesterolemia. (c) There is storage of cholesterol esters in hepatocytes and Kupffer cells. Both parents are phenotypically normal. However, they have only approximately half-normal LAL activity in white blood cells. This is also consistent with the supposed inheritance of CESD (2).

Analysis of RNA from fibroblasts and white blood cells showed that the patient had only one mRNA for LAL that lacked 72 bp compared to the wild-type mRNA. In that this deletion contains a Xbal site, it was possible to distinguish between a deletion in the genome and a posttranscriptional event, e.g., a splicing defect. Southern blotting showed that the Xbal site is present in the genome of the patient and his mother who transmitted the defective allele. In fact, the deleted fragment could be shown by genomic sequencing to represent an entire exon, indicating that exon skipping leads to truncation of the mRNA. When the 5' and 3' splice junctions of the exons were sequenced, the only difference to the wild-type sequence was a $\mathrm{G} \rightarrow \mathrm{A}$ transition in the last base of the 72-bp exon of the patient. This $G \rightarrow A$ transition was also detected in the mother's and older brother's genome, whereas it is not present in the father's DNA. This demonstrates cosegregation of the mutant allele and the truncated mRNA and is evidence for a

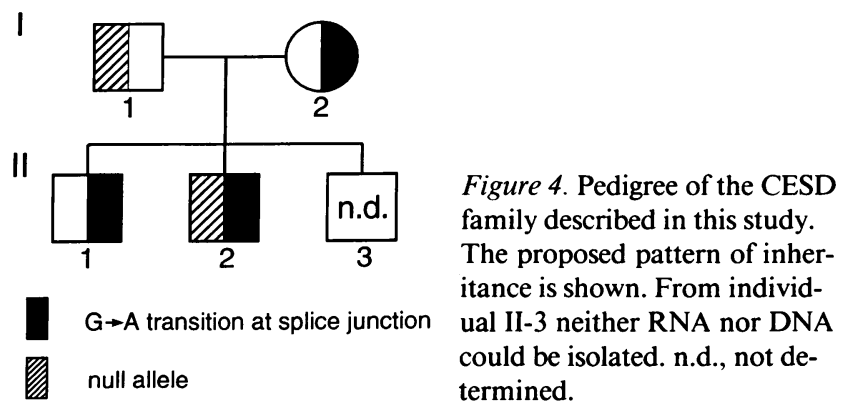

causal relationship between the two. In the literature five more cases of a $\mathrm{G} \rightarrow \mathrm{A}$ transition in the last base of an exon leading to exon skipping have been reported (22-25).

Genomic sequencing proved that the patient is heterozygous at the LAL locus. One allele has the $G \rightarrow A$ transition, whereas the other has the wild-type sequence. Thus, one would expect, in addition to the truncated mRNA, a normal-sized mRNA, which is not the case. There are only two possible explanations for this observation. There might be another splicing defect leading to a similar truncation of the mRNA. This is highly unlikely, because the splice junctions have been sequenced and are normal. In addition, one would expect to detect a truncated mRNA in the father in this case. The second, much more likely, explanation is the presence of a null allele which is not expressed or leads to a highly unstable mRNA. The assumption of the presence of a null allele would explain the pedigree data including the reduced LAL activity in the leukocytes of the patient's father. To solve this matter conclusively, we are currently in the process of analyzing the promoter region of the LAL gene. Fig. 4 summarizes the proposed pattern of inheritance at the LAL locus in the family presented here.

In that skipping of the 72-bp exon does not disrupt the reading frame, the mutant mRNA was expected to be translated into a truncated protein missing 24 amino acid residues encoded by the 72-bp exon. The deletion does not include the putative active esterase site with the consensus sequence for serine esterases G-X-S-X-G. In addition, it does not affect potential sites for $\mathrm{N}$-glycosylation. No cysteine is within the 24amino acid deletion. Nevertheless, there appears to be a severe reduction of the activity of the truncated protein. This may be related to conformational changes in the protein structure. Alternatively, the defective protein may be degraded immediately posttranslationally or not be transported properly to the lysosome. Further studies that use expression vectors with the mutant LAL are necessary to elucidate the mechanism leading to the loss of LAL activity.

The patient and his father have low HDL cholesterol and apoA-I. The reason for hypoalphalipoproteinemia in these two cases is not known. There have been several cases of CESD with low HDL (2). In fact, a separate genetic defect leading to low HDL cannot be ruled out.

In summary, a genetic defect leading to CESD has been described in a small kindred of central European origin. It is a combination of an allele which is abnormally spliced due to a point mutation, leading to a 72-bp deletion from the mature mRNA, with a nonfunctional allele. 


\section{Acknowledgments}

The expert technical assistance of Ulrike Stoeckl is gratefully acknowledged.

This study was supported in part by the Deutsche Forschungsgemeinschaft within the SFB 310.

\section{References}

1. Goldstein, J. L., and M. S. Brown. 1977. The low-density lipoprotein pathway and its relation to atherosclerosis. Annu. Rev. Biochem. 46:897-930.

2. Schmitz, G., and G. Assmann. 1989. Acid lipase deficiency: Wolman disease and cholesteryl ester storage disease. In The Metabolic Basis of Inherited Disease. 6th edition. C. R. Scriver, A. L. Beaudet, W. S. Sly, and D. Valle, editors. McGraw-Hill, Inc., New York. 1623-1644.

3. Marshall, W. C., B. C. Ockenden, A. S. Fosbrooke, and J. N. Cumings 1969. Wolman's disease: a rare lipidosis with adrenal calcification. Arch. Dis. Child. 44:331-341.

4. Suzuki, Y., S. Kawai, A. Kobayashi, Y. Ohbe, and H. Endo. 1976. Partia deficiency of acid lipase with storage of triglycerides and cholesterol esters in liver. Clin. Chim. Acta. 69:219-224.

5. Ozoran, Y., Y. Ozoran, I. Kerse, A. Gürgey, S. Ozsoylu, N. Koccak, and G. Ciliv. 1978. An ultrastrutural study in a case of Wolman's disease (clinical, biochemical, light and electron microscopic study). Turk. J. Pediatr. 20:100-107.

6. Schaub, J., G. E. Janka, H. Christomanou, K. Sandhoff, W. Permanetter, G. Hübner, and P. Meister. 1980. Wolman's disease: clinical, biochemical and ultrastructural studies in an unusual case without striking adrenal calcification. Eur. J. Pediatr. 135:45-53.

7. Coates, P. M., T. Langert, and J. A. Cortner. 1986. Genetic variations of human mononuclear leukocyte lysosomal acid lipase activity: relationship to atherosclerosis. Atherosclerosis. 62:11-20.

8. Yatsu, F., F. Hagemenas, L. Manaugh, and T. Galumbos. 1980. Cholesteryl ester hydrolase activity in human symptomatic atherosclerosis. Lipids. 15:1019-1022.

9. Hagemenas, F. C., L. C. Manaugh, D. R. Illingworth, E. E. Sundberg, and F. M. Yatsun. 1984. Cholesteryl ester hydrolase activity in mononuclear cells from patients with Type III hypercholesterolemia. Atherosclerosis. 50:335-344.

10. Tomita, T., Y. Shirasaki, Y. Takiguchi, Y. Ozaki, and E. Hayashi. 1980. Hemodynamic effects on aortic enzyme activities in spontaneously hypertensive rats. Atherosclerosis. 37:409-422.

11. Wolinsky, H., L. Capron, S. Goldfisher, F. Capron, B. Coltoff-Schiller, and L. E. Kasak. 1978. Hydrolase activities in the rat aorta. 2. Effect of hyperten sion alone and in combination with diabetes mellitus. Circ. Res. 42:831-839.

12. Nguyen, V. C., D. Weil, M. C. Hors-Cayla, M. S. Gross, S. Heuertz, C. Foubert, and J. Fresal. 1980. Assignment of the genes for human lysosmal acid lipases A and B to chromosomes 10 and 16. Hum. Genet. 55:375-383.

13. Koch, G., P. A. Lalley, M. Mcavoy, and T. B. Shows. 1981. Assignment of LIPA, associated with human lipase deficiency to human chromosome 10 and comparative assignment to mouse chromosome 19. Somatic Cell. Genet. 7:345358.

14. Anderson, R. A., N. Rao, R. S. Byrum, C. B. Rothschild, D. W. Bowden, R. Hayworth, and M. Pettentai. 1993. In situ localisation of the genetic locus encoding the lysosomal acid lipase/cholesteryl esterase (LIPA) deficient in Wolman disease to chromosome 10q23.2-q23.3. Genomics. 15:245-247.

15. Anderson, R. A., and G. N. Sando. 1991. Cloning and expression of cDNA enconding human lysosomal acid lipase/cholesteryl ester hydrolase. $J$. Biol. Chem. 266:22479-22484.

16. Chirgwin, J. M., A. E. Przybyla, R. J. MacDonald, and W. J. Rutter. 1979. Isolation of biologically active ribonucleic acid from sources enriched in ribonuclease. Biochemistry. 18:5294-5299.

17. Miller, S. A., D. D. Dykes, and H. F. Polsky. 1988. A simple salting out procedure for extracting DNA from human nucleated cells. Nucleic Acids Res. 16:1215.

18. Sanger, F., S. Nicklen, and A. R. Coulson. 1977. DNA sequencing with the chain-terminating inhibitors. Proc. Natl. Acad. Sci. USA. 74:5463-5467.

19. Sambrook, J., E. F. Fritsch, and T. Maniatis. 1989. Molecular Cloning: A Laboratory Manual, 2nd edition. Cold Spring Harbor Laboratory Press, Cold Spring Harbor, NY.

20. Haley, N. J., S. Fowler, and C. De Duve. 1980. Lysosomal acid cholesteryl esterase activity in normal and lipid-laden aortic cells. J. Lipid Res. 21:961-969.

21. Lowry, O., N. J. Rosebrough, A. L. Farr, and R. J. Randall. 1951. Protein measurement with the folin phenol reagent. J. Biol. Chem. 193:265-275.

22. Krawczak, M., J. Reiss, and D. N. Cooper. 1992. The mutational spectrum of single base-pair substitutions in mRNA splice junctions of human genes: causes and consequences. Hum. Genet. 90:41-54.

23. Grandchamp, B., C. Picat, F. de Rooij, C. Beaumont, P. Wilson, J. C Deybach, and Y. Nordmann. 1989. A point mutation $G \rightarrow A$ in the exon 12 of the porphobilinogen deaminase gene results in exon skipping and is responsible for acute intermittent porphyria. Nucleic Acids Res. 17:6637-6649.

24. Weil, D., M. D’Alessio, F. Ramirez, B. Steinmann, M. K. Wirtz, R. W Glanville, and D. W. Hollister. 1989. Temperature-dependent expression of a collagen splicing defect in the fibroblasts of a patient with Ehlers-Danlos syndrom type VII. J. Biol. Chem. 264:16804-16809.

25. Akli, S., J. Chelly, C. Mezard, S. Gandy, A. Kahn, and L. Poenaru. 1990. A $\mathrm{G}$ to $\mathrm{A}$ mutation at position -1 of a $5^{\prime}$ splice site in a late infatile form of Tay-Sachs disease. J. Biol. Chem. 265:7324-7330. 